\title{
American
}

Journal of

International

Law

\section{January 2005}

Vol. 99 No. 1

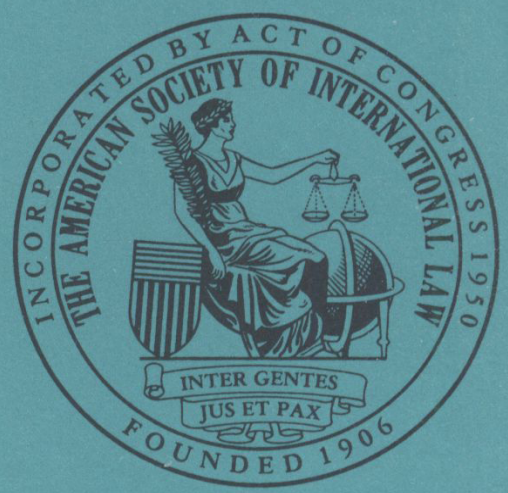

Published by

The American Society of International Law 


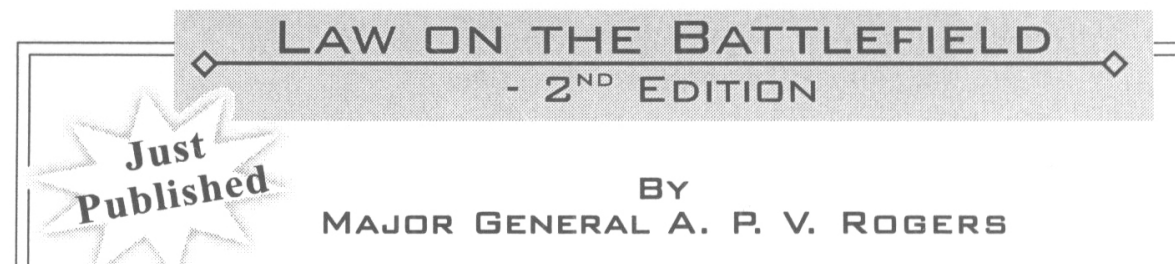

\$90. 1 Hardcover Volume. 275 pages. Index. ISBN 1-929446-57-8

\$52. 1 Softcover Volume. ISBN 1-929446-58-6

Author: Major General A. P. V. Rogers is Yorke Distinguished Visiting Fellow, Faculty of Law, University of Cambridge, Fellow of the Lauterpacht Research Centre for International Law, University of Cambridge, Fellow of the Human Rights Centre, University of Essex, and member of the International Fact-Finding Commission. $\mathrm{He}$ is the Former Director of Legal Services of the British Army and is General Editor of the UK Armed Forces Manual of Armed Conflict

\section{Praise for "Law on the Battlefield"}

"This book makes a most useful contribution to the understanding of the law of war. It takes key provisions of the 1977 Geneva Protocol I and explains their context, their negotiating history as well as their meaning and relevance today. I commend it not only to military lawyers but also to those who plan and conduct operations of peacekeeping and war. The book will also appeal to those who would like to resolve in their own minds the apparent incompatibility between law and war:"

- General Sir Michael Rose, Former Commander of the UN Protection Force in Bosnia. General Sir Michael Rose KCB CBE DSO QGM, following service with the SAS in Malaya and Oman, commanded the 22nd SAS Regiment (1979-82) during which time it was involved in the London Iranian Embassy siege and the Falklands War. From January 1994 to January 1995 he assumed command of the UN Protection Force in Bosnia after which he became Adjutant General and a member of the Army Board.

"Critical observers, whether among the military, media or in academe, are in need of expert exposition of the intricacies of battlefield law as it has evolved over time. For these reason this book is to be warmly welcomed."

- Frits Kalshoven, Professor Emeritus of Public International Law and International Humanitarian Law, University of Leiden. He took part in the conferences that drafted the 1977 Additional Protocols and the 1981 Conventional Weapons Convention, and acted as first chairman of the UN Commission of experts on war crimes in the former Yugoslavia (1992-1993).

"Law on the Battlefield proves an important addition to the understanding and dissemination of the law of armed conflict. It is well-written and well-documented, covers the ground it intended to in a comprehensive fashion, is replete with relevant examples from actual operations of the principles discussed, and evidences a keen grasp by the author of the practicalities involved when combat confronts law. General Rogers is to be complimented, and thanked, for narrowing the gap between practitioner and commentator. There is little doubt that Law on the Battlefield should be included in the library of anyone-academic, judge advocate, or operator-concerned with the conduct of armed conflict."

- Professor Michael N. Schmitt is the Director of the Program in Advanced Security Studies and Professor of International Law in the College of International and Security Studies, George C. Marshall European Center for Security Studies, Garmisch-Partenkirchen, Germany.

"Law on the Battlefield may prove most useful for the army legal adviser, but those in the legal services of both the air force and the navy will find sufficient material to help them in their duties as advisers. They will often be able, without undue effort, to adapt them to their own specific problems.

- Leslie C. Green Charles H. Stockton Chair of International Law Naval War College 


\section{AMERICAN JOURNAL OF}

\section{INTERNATIONAL LAW}

VOL. 99

January 2005

NO. 1

CONTENTS

PAGE

Agora: ICJ Advisory Opinion on Construction of a Wall in the Occupied Palestinian Territory

Editors' Introduction Lori Fisler Damrosch and Bernard H. Oxman

The "Wall" Decisions in Legal and Political Context

Geoffrey R. Watson 6

The ICJ's Advisory Jurisdiction and the Crumbling Wall Between the Political and the Judicial

Toward Authoritativeness: The ICJ Ruling on Israel's Security Wall

Michla Pomerance 26

The ICJ Advisory Opinion on the Israeli Security Fence and the Limits of Self-Defense

Self-Defense and the Israeli Wall Advisory Opinion: An Ipse Dixit from the ICJ?

Richard A. Falk 42

Ruth Wedgwood 52

Words My Mother Never Taught Me- "In Defense of the International Court"

Sean D. Murphy

The Advisory Opinion: The Light Treatment of International Humanitarian Law

Iain Scobbie

Critical Reflections on the International Humanitarian Law Aspects of the ICJ Wall Advisory Opinion

David Kretzmer

Application of Human Rights Treaties Extraterritorially in Times of Armed Conflict and Military Occupation

Michael J. Dennis

Notes and Comments

The Judicial Effects of the "Completion Strategies" on the Ad Hoc International Criminal Tribunals

Closing an International Criminal Tribunal While Maintaining International Human Rights Standards and Excluding Impunity

The Security Council as World Legislature

Daryl A. Mundis

\section{Current Developments}

The UN Convention on Jurisdictional Immunities of States and Their Property

The Fifty-sixth Session of the International Law Commission

\section{International Decisions}

Assanidze v. Georgia (Alexander Orakhelashvili)

European Court of Human Rights judgment on the rights to liberty and security and to a fair hearing

Biret International SA v. Council of the European Union; Etablissements Biret $\mathcal{E}$ Cie SA v. Council of the European Union (Patricia Egli)

European Court of Justice ruling on whether EC beef hormone import violation of the WTO SPS Agreement gives rise to private rights under EC law 
Ferrini v. Federal Republic of Germany (Andrea Bianchi)

Italian Court of Cassation ruling on immunity from suit for damages for deportation and forced labor during World War II

Airport Linz v. United States (Stephan Wittich)

Austrian Supreme Court decision on immunity from suit for landing fees for Air

Force planes supporting NATO humanitarian operations in Bosnia

\section{Contemporary Practice of the United States Relating to International Law}

United States Lifts Some Sanctions on Libya

Edited by John R. Crook

U.S. Relations with Republic of Macedonia

U.S. Responses to Alleged Abuse of Oil-for-Food Program

Nongovernmental Bodies Standardize Bar Codes

United States Whaling Policy

U.S. Market-Based Partnership to Reduce Methane Emissions

Arctic Council Policy Document on Global Warming

Repeal of U.S. Tax Benefit for Exporters

Requests for Safeguards on Apparel from China

U.S. Policy Regarding Internet Governance

Updated U.S. Model BIT

New BIT Model Followed in New Treaty with Uruguay

Paris Club Agrees to Substantial Debt Relief for Iraq

United States, Australia Settle Disputes Blocking U.S.-Australian Free Trade Agreement

Treatment of U.S. Detainees at Guantánamo Bay

Supreme Court Litigant Released to Return to Saudi Arabia

Proceedings Involving Possible Offenses Against Protected Persons in Iraq and Afghanistan

ICRC Report Alleges Interrogation Techniques "Tantamount to Torture"

Religious Freedom Report Cites Eight Countries, Including Saudi Arabia

Human Trafficking: Proposal to Criminalize the Patronization of Prostitutes by U.S. Service Members

Reported Removal of Prisoners from Iraq

Efforts to Ban Human Cloning

President and Secretary of State Characterize Events in Darfur as Genocide

United States Supports Security Council Anti-terrorism Resolution

United States Vetoes Resolution to Condemn Israeli Incursion in Gaza

Legality of U.S.-Led Invasion of Iraq

Iran's Nuclear Program

U.S. Initiates Arbitration Against India over OPIC Claims for the Dabhol Power Project

U.S. Appeals Adverse NAFTA Panel Ruling on Softwood Lumber

\section{Book Reviews}

Rosenne, Shabtai. The Perplexities of Moderm International Law (Anne Orford)

Benvenisti, Eyal. Sharing Transboundary Resources: International Law and Optimal Resource Use (Daniel Bodansky)

Volger, Helmut (ed.). A Concise Encyclopedia of the United Nations (Ruth Wedgwood)

Bassiouni, M. Cherif. Introduction to International Criminal Law (Mark A. Drumbl)

Shaffer, Gregory C. Defending Interests: Public-Private Partnerships in WTO Litigation (William J. Davey)

Macedo, Stephen (ed.). Universal Jurisdiction: National Courts and the Prosecution of Serious Crimes Under International Law (Kenneth C. Randall)

Baderin, Mashood A. International Human Rights and Islamic Law (Ann Elizabeth Mayer)

Keal, Paul. European Conquest and the Rights of Indigenous Peoples: The Moral Backwardness of International Society (S. James Anaya)

\section{Briefer Notice}

Schermers, Henry G., and Niels M. Blokker (eds.). International Institutional Law: Unity Within Diversity (4th rev. ed.) (Kelly Vinopal)

International Legal Materials. Contents, Vol. XLIII, No. 6 (November 2004); Vol. XLIV, No. 1 (January 2005) 


\section{BOARD OF EDITORS}

Editors in Chief

LORI FISLER DAMROSCH

Columbia University School of Law

JOSÉ E. AlLVAREZ

Columbia University School of Law

DAVID J. BEDERMAN

Emory University School of Law

DANIEL BODANSKY

University of Georgia School of Law

DAVID D. CARON

Univ. of California (Berkeley) School of Law

Hilary CHARL ESWORTH

Australian National University

STEve CHARnovitz

George Washington Univ. Law School

Christine M. CHINKIN

London School of Economics

JAMES R. CRAWFORD

University of Cambridge

JOHN R. CROOK

Potomac, Maryland

JACK L. GOLDSMITH

Harvard Law School

BENEDICT KINGSBURY

New York University School of Law

DAVID A. MARTIN

University of Virginia School of Law
JAMES H. CARTER ex officio

\section{Honorary Editors}

GEORGE H. ALDRICH

The Hague, the Netherlands

RICHARD B. BILDER

University of Wisconsin Law School

CHARLES N. BROWER

The Hague, the Netherlands

THOMAS BUERGENTHAL

The Hague, the Netherlands

RICHARD A. FALK

University of California at Santa Barbara

TOM J. FARER

University of Denver

THOMAS M. FRANCK

New York University School of Law

LOUIS HENKIN

Columbia University School of Law

ROSALYN HIGGINS

The Hague, the Netherlands

JOHN H. JACKSON

Georgetown University Law Center

FREDERIC L. KIRGIS

Washington and Lee Univ. School of Law
BERNARD H. OXMAN

University of Miami School of Law

MiCHAEL J. MATHESON

George Washington Univ. Law School

SEAN D. MURPHY

George Washington Univ. Law School

STEVEN R. RATNER

University of Michigan Law School

DINAH L. SHELTON

George Washington Univ. Law School

BETH A. SIMMONS

Harvard University

RICHARD H. STEINBERG

Univ. of California (LA) School of Law

JANE E. STROMSETH

Georgetown University Law Center

JOEL P. TRACHTMAN

Fletcher School of Law and Diplomacy

RUTH WEDGWOOD

Johns Hopkins University

EDITH BROWN WEISS

Georgetown University Law Center

DIANE P. WOOD

Chicago, Illinois

\author{
ANDREAS F. LOWENFELD \\ New York University School of Law \\ THEODOR MERON \\ The Hague, the Netherlands \\ JOHN NORTON MOORE \\ University of Virginia School of Law \\ COVEY T. OLIVER \\ Easton, Maryland \\ W. MICHAEL REISMAN \\ Yale Law School \\ STEPHEN M. SCHWEBEL \\ Washington, D.C. \\ LOUIS B. SOHN \\ George Washington Univ. Law School \\ ERIC STEIN \\ University of Michigan Law School \\ DetLeV F. VAGTS \\ Harvard Law School \\ BURNS H. WESTON \\ University of Iowa College of Law
}

\author{
Senior Associate Editor \\ ANNA ASCHER
}

Associate Editor

Managing Editor

Assistant Editors
STEPHEN SCHER 


\section{THE AMERICAN SOCIETY OF INTERNATIONAL LAW}

The American Society of International Law was organized in 1906 "to foster the study of international law and to promote the establishment and maintenance of international relations on the basis of law and justice." Society membership is open to all persons of any nationality and profession who are interested in its objectives. Dues are: regular, $\$ 165$; special category, $\$ 110$; new professional, $\$ 85$; retired, $\$ 110$; student, $\$ 30$. Sustaining Memberships-contributing $(\$ 275)$ and patrons $(\$ 10,000)$-are also available. Corporations may join ASIL as institutional members $(\$ 2,000)$. The Society is incorporated by Act of Congress approved September 20, 1950 (64 Stat. 869).

\section{OFFICERS OF THE SOCIETY, 2004-2005}

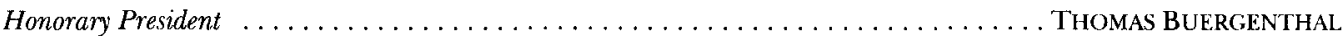
President $\ldots \ldots \ldots \ldots \ldots \ldots \ldots \ldots \ldots \ldots \ldots \ldots \ldots \ldots \ldots \ldots \ldots \ldots \ldots \ldots \ldots \ldots \ldots \ldots \ldots \ldots \ldots$ JAM. CARTER

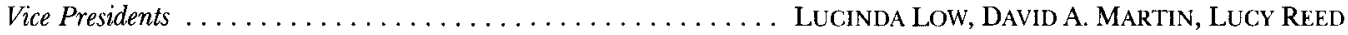
Executive Vice President and Executive Director $\ldots \ldots \ldots \ldots \ldots \ldots \ldots \ldots \ldots \ldots \ldots \ldots$ CHARLOTTE KU

Past Presidents: Charles N. Brower, Thomas M. Franck, Louis Henkin, Covey T. Oliver, William D. Rogers, arthur W. Rovine, ANNe-Marie Slaughter, Louis B. SOHN, PeTER D. Trooboff, EdTth Brown WeisS

Honorary Vice Presidents: ThOMAS M. Franck, ARTHUR W. Rovine, ANNE-MARIE SLAUGHTER

Counsellors: JAMES BACCHUS, ROSEMARY BARKETT, RICHARD B. BILDER, LAN BROWNLIE, HILARY CHARLESWORTH, LORI FISLER DAMROSCH, PIERRE-MARIE DUPUY, TOM J. FARER, JOHN King GAMble, CONRAD HARPER, RITA E.

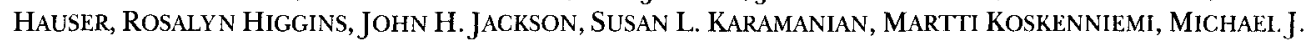

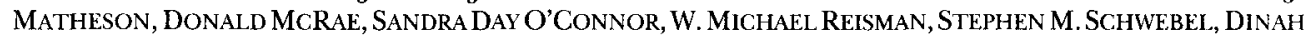
L. Shelton, Jerome Shestack, Patricia Wald, Edwin D. Williamson

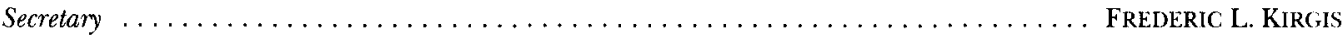

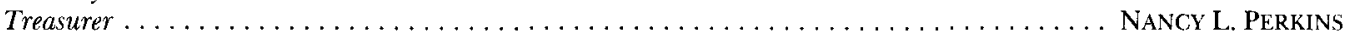
Assistant Treasurer $\ldots \ldots \ldots \ldots \ldots \ldots \ldots \ldots \ldots \ldots \ldots \ldots \ldots \ldots \ldots \ldots \ldots \ldots \ldots \ldots \ldots \ldots$ KENT BRESSIE

\section{PATRONS OF THE SOCIETY}

DOMINGO E. ACEVEDO

GERALD AKSEN

ARTHUR R. ALBRECHT

GEORGE H. ALDRICH

TEYMOUR A. AlIREZA

José ALVAREZ AND SUSAN DAMPLO

JAMES G. APPLE

MAHNOUSH H. ARSANJANI

FRANK A. BAUMAN

MRS. RICHARD BAXTER*

DAVID J. BEDERMAN AND LORRE B. CUZZE

DANIEL L. BETHLEHEM

RICHARD B. BILDER

JOHN A. BOYD

CHARLES N. BROWER

IAN BROWNLIE

THOMAS BUERGENTHAL

RODMAN R. BUNDY

WiLliaM J. BUTLER

SUSANA AND HUGO CAMINOS

Charles H. Camp

DAVID D. CARON

JAMES H. CARTER

JAMES RICHARD CRAWFORD

JOHN R. CROOK

ANTHONY D'AMATO

LORI FISLER DAMROSCH AND

JEAN BAUER FISLER

ARTHUR H. DEAN*

ELI WHITNEY DEBEVOISE II

SARAH WHITCRAFT DEFORD*

EDWARD DUMBAULD*

RICHARD W. EDWARDS, JR.

Alona E. Evans*

BENJAMIN B. FERENCZ

"deceased

ALEXANDER FREEMAN ARTHUR K. KUHN

THOMAS M. FRANCK
ALWYN V. FREEMAN
JOHN KING GAMBLE
RONALD E. M. GOODMAN
KATHERINE GOROVE
CHRISTOPHER J. GREENWOOD
JOHN LAWRENCE HARGROVE
VICTORIA M. HARIRI
RITA E. HAUSER
JOHN N. HAZARD*
ALICE AND LOUIS HENKIN
KEITH HIGHET
HOWARD M. HOLTZMANN
CHARLES A. HUNNICUTT
JOHN H. JACKSON
MARK R. JOELSON
RICHARD A. JOHNSON
SUSAN L. KARAMANIAN
FREDERIC L. KIRGIS
CHARLOTTE KU
JENNIFER LAKE AND DONALD
FRANCIS DONOVAN
JEFFREY LANG
ELIHU LAUTERPACHT
ROY S. LEE
JEREMY I. AND CANDACE C.
LEVITT
CYNTHIA CRAWFORD
LICHTENSTEIN
MRS. RICHARD LILLICH
A. VAUGHAN LOWE
ANDREAS F. LOWENFELD
BRUNSON MACCHESNEY*
ROBERT MACCRATE
RONALD ST. JOHN MACDONALD
EDWARD WATSON MCWHINNEY

\section{In Memoriam}

HENRY C. MORRIS

\section{PATRONAGE, GIFTS, AND BEQUESTS}

\author{
ROBERT F. MEAGHER \\ HUSAM MESHAL \\ W. ROBERT MORGAN* \\ VED P. NANDA \\ ANDRE NEWBURG; \\ BERNARD H. OXMAN \\ NANCY L. PERKINS \\ Herman PhLEger \\ LUCY F. REED \\ W. MICHAEL REISMAN \\ ANDRÉS RIGO \\ DAVIS R. ROBINSON \\ WILLIAM D. ROGERS \\ ARTHUR W. ROVINE \\ SEYMOUR J. RUBIN* \\ PHILIPPE J. SANDS \\ OSCAR SCHACHTER \\ STEPHEN M. SCHWEBEL \\ ANNE-MARIE SIAUGHTER \\ ABBX COHEN SMUTNY \\ EARL A. SNYDER* \\ BARBARA STARK \\ ERIC STEIN \\ JOHN R. STEVENSON* \\ ENRIQUE P. SYQUIA \\ Genevieve E. TILlaR* \\ PeTER D. TROobofF \\ DETLEV F. VAGTS \\ Charles $O$. VERRILl, JR. \\ JILL MCCLANAHAN WATSON \\ RUTH WEDGWOOD \\ EDITH BROWN WEISS \\ BURNS H. WESTON \\ EDWIN D. WILLIAMSON \\ BASIL S. YANAKAKIS \\ NASSIB G. ZIADÉ
}

\section{JAMES BROWN SCOTT STANLEY P. SMITH}

Upon donation to the Society of $\$ 10,000$ or more, any member of the Society or individual eligible for membership may be elected a Patron of the Society. Upon donation of at least $\$ 10,000$ in the name of a deceased person, such person may be elected a Patron posthumously. Bequests or other estate gifts are also accepted independently of the Patrons program. Gifts and bequests may be made in the name of the American Society of International Law, Washington, DC. Such contributions may be tax-deductible to the extent allowed by law. 


\section{ORDERS AND INQUIRIES}

Subscriptions, Back Issues, and Cumulative Indexes: The American Journal of International Law (ISSN 0002-9300) is published quarterly, in January, April, July, and October, and is supplied to all members of the American Society of International Law. The annual subscription rate for nonmembers is $\$ 180$ ( $\$ 220$ outside U.S.). Inquiries should be sent to the American Journal of International Law, 2223 Massachusetts Avenue, NW, Washington, DC 20008-2864; fax (202) 797-7133. Annual subscription orders should be sent to P.O. Box 164, Washington, DC 20055-0164. Order forms and other information are available online at <http://www.asil. org $>$. Claims for undelivered issues must be made in writing to the Society within three months of the mailing date specified online at <http://www.asil.org/claims.htm>. Volumes 1 (1907) to date are available from William S. Hein \& Co., Inc., 1285 Main Street, Buffalo, NY 14209-1987, USA, toll-free (800) 828-7571. Cumulative indexes are also available from Hein: 1941-1960, 1961-1970, 1971-1980, and 1981-1990.

\section{$A J I L$ is also available in nonprint forms:}

- Online, through: Hein Online, a service of William S. Hein \& Co., Inc., at < http:// www.heinonline.org >; Mead Data Central, Inc., provider of the LEXIS ${ }^{\oplus} /$ NEXIS $^{\oplus}$ services, P.O. Box 933, Dayton, OH 45401, USA, toll-free (800) 227-9597; and West Publishing Company, provider of WESTLAW ${ }^{\circledR}$, P.O. Box 64526, St. Paul, MN 55164-0526, USA, toll-free (800) 937-8529.

- On the Web in JSTOR, the archive/database of scholarly journals, either through individual subscriptions by ASIL members only ((202) 939-6000), or through institutional subscriptions (JSTOR, 149 Fifth Avenue, 8th Floor, New York, NY 10010, (212) 3586400 ). See < http://www.jstor.org > for a current list of institutional subscribers.

- On microform, from: William S. Hein \& Co., Inc., 1285 Main Street, Buffalo, NY 14209, USA, toll-free (800) 828-7571; and University Microfilms, 300 North Zeeb Road, Dept. P.R., Ann Arbor, MI 48106, USA, toll-free (800) 521-0600; or 30-32 Mortimer Street, Dept. P.R., London WIN 7RA, England.

- On CD-ROM format, from: University Microfilms.

Authorization to photocopy items for internal or personal use (beyond that permitted by sections 107 and 108 of the U.S. Copyright Law), or for the internal or personal use of specific clients, is granted by the American Society of International Law for users registered with the Copyright Clearance Center (CCC) Transactional Reporting Service, provided that the base fee of $\$ 5$ per copy, plus $25 \not$ per page, is paid directly to CCC, 222 Rosewood Drive, Danvers, MA 01923. For organizations that have been granted a photocopy license by CCC, a separate system of payment has been arranged. The fee code for users of the Transactional Reporting Service is: $0002-9300 / 02 \$ 5.00+.25$. Educational copying is permitted. Please address requests to CCC Academic Permission Service: tel. (978) 750-8400; fax (978) 750-4744.

Advertising: Inquiries should be sent to the Marketing Manager, ASIL, 2223 Massachusetts Avenue, NW, Washington, DC 20008-2864, tel. (202) 939-6000; fax (202) 797-7133.

Periodicals postage paid at Washington, DC, and at additional mailing office. POSTMASTER: Send change of addresses to American Journal of International Law, 2223 Massachusetts Ave., NW, Washington, DC 20008-2864. 


\section{AMERICAN JOURNAL OF INTERNATIONAL LAW}

The views expressed in the articles, editorial comments, book reviews, and all other contributions to the $A J I L$ are those of the individual authors and are not to be taken as representing the views of the Board of Editors or the American Society of International Law.

\section{SUBMISSION OF MANUSCRIPTS}

Manuscripts may be sent to the American Journal of International Law, at the American Society of International Law, 2223 Massachusetts Avenue, NW, Washington, DC 20008-2864, USA, or by e-mail to AJIL@ASIL.org. Authors are requested to submit their manuscripts on computer disc or by e-mail attachment. If the manuscript is unavailable in electronic form, four paper copies should be submitted. Manuscripts and discs submitted will not be returned to the author. Please do not submit manuscripts via facsimile. The $A J I L$ will not consider submissions whose content has been, or will be, published before it appears in this Journal.

The AJIL uses WordPerfect 9 and can convert manuscripts created in other word-processing programs into that program. Please specify the word-processing program used for manuscripts submitted in electronic form.

Book reviews are by invitation: suggestions may be made to the Book Review Office, 2223 Massachusetts Avenue, NW, Washington, DC 20008-2864. Books for review should be sent to the same office.

Format and style guidelines: All manuscripts should be double-spaced, with double-spaced footnotes. Our full Author Style Sheet is available online at $<\mathrm{http}: / \mathrm{www}$.asil.org/styledoc.htm $>$. Subject to variations noted in that document, the AJIL conforms to The Bluebook: A Uniform System of Citation (17th ed. 2000) and the Chicago Manual of Style (14th ed. 1993). The style document can also be obtained via e-mail; please send e-mail requests to AJIL@ASIL.org.The Bluebook can be obtained from the Harvard Law Review Association, Gannett House, 1511 Massachusetts Avenue, Cambridge, MA 02138.

\section{INDEXES CARRYING $A J I L$}

The American Journal of International Law is included in: ABC POL SCI: A Bibliography of Contents: Political Science and Government; Current Law Index; IBR-International Bibliography of Book Reviews of Scholarly Literature; IBZ - International Bibliography of Periodical Literature; Index to Foreign Legal Periodicals, Index to Legal Periodicals; Intermational Political Science Abstracts; Public International Law: A Current Bibliography of Books and Articles; Social Sciences Index. 